\section{Tore forteller om tarmfloraen}

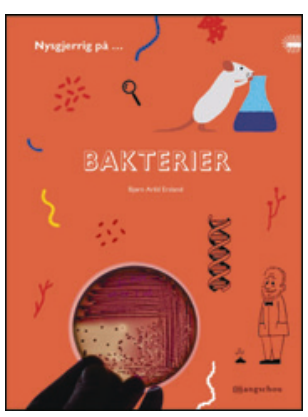

Bjørn Arild Ersland

\section{Nysgjerrig på... bakterier}

100 s, ill. Bergen: Mangschou Forlag, 2013. Pris NOK 235

ISBN 978-82-8238-068-3

Den norske legen Tore Midtvedt (f. 1934) er professor emeritus i medisinsk mikrobiell økologi ved Karolinska Institutet i Stockholm. I denne faktaboken for barn fremstilles han som en klok og bestefaraktig tegneseriefigur, sjarmerende illustrert av Espen Friberg. Vi blir kjent med Midtvedt og hans omfattende forskningsaktivitet gjennom egne avsnitt med overskriften Tore forteller. Tore har forsket på bakterier i mer enn 50 år og står fortsatt opp grytidlig om morgenen for å arbeide. Han har mange historier å fortelle.

Nysgjerring på... bakterier handler først og fremst om kroppens normale bakterieflora, men vi kan også lese om livets opprinnelse og evolusjon, om bakteriologiens historie og utvikling og om sykdomsskapende mikrober og deres bekjempelse. Underveis forteller Tore om astronauter, kameler og sirtuiner. Fremstillingen er lettlest, underholdende og rikt illustrert. Det forekommer enkelte faktafeil, for eksempel at E. coli-smitten i Tyskland i 2011 kom fra importerte agurker (s. 50), og at terrorangrepet 11. september skjedde i 2011 (s. 55), men dette forstyrrer ikke helhetsinntrykket. Alt i alt er dette et vellykket formidlingsprosjekt som treffer målgruppen godt.

Den gjengse medisiner har brukt forholdsvis lang tid på å innse at normalfloraen har helsemessig betydning. Tore Midtvedt er ingen gjengs medisiner og skrev om dette i Tidsskriftet allerede i 1967 (1). Nå er tarmfloraen ikke lenger en kuriositet forbeholdt spesielt interesserte mikrobiologer - men et sentralt forskningsfelt som angår alle leger. Nysgjerrig på... bakterier vil forhåpentligvis inspirere mange tarmfloraforskerspirer.

\section{Jørgen Valeur}

Unger-Vetlesens institutt

Lovisenberg Diakonale Sykehus

\section{Litteratur}

1. Midtvedt T. Tarmfloraens fysiologiske betydning. Tidsskr Nor Lægeforen 1967; 87: 255

Oppgitte interessekonflikter: Anmelderen kjenner Tore Midtvedt gjennom forskningssamarbeid.

\section{Atferdsanalyse i miljøet}

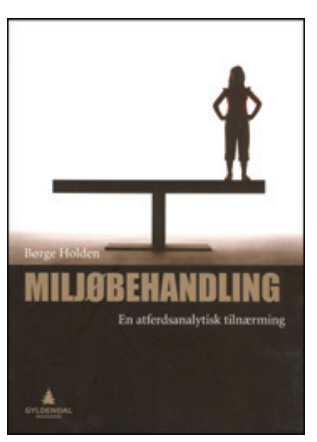

Børge Holden

Miljøbehandling

En atferdsanalytisk tilnærming.

275 s. Oslo: Gyldendal Akademisk, 2013.

Pris NOK 345

ISBN 978-82-05-44862-9

Målgruppen er studenter i helse- og sosialfag, i tillegg til personer som jobber systematisk med endring av atferd hos personer som har utviklet et problematisk atferdsmønster. Forfatteren er spesialist i klinisk voksenpsykologi og har klinisk erfaring knyttet til personer med psykisk utviklingshemning og utviklingsforstyrrelser.

Det hevdes at boken er en grunnleggende introduksjon til miljøbehandling og atferdsanalyse, og forfatteren vil vise at atferdsanalytiske teknikker kan være en effektiv behandlingsform for en rekke ulike lidelser hvor problematisk atferd har fått utvikle seg. Dette gjelder alt fra problematisk atferd hos personer med psykisk utviklingshemning til atferds- og utviklingsforstyrrelser hos barn og unge, personlighetsforstyrrelser, depressive lidelser, ulike angstog fobiske tilstander, maniske tilstander, rus og psykotiske lidelser.

De 15 kapitlene etterfølges av en referanseliste og et kort stikkordregister. Det er ingen tabeller eller illustrasjoner. I de første kapitlene beskriver forfatteren relativt lettfattelig prinsippene bak atferdsanalyse. Det gjelder begreper som omhandler funksjonelle analyser, ulike aspekter ved passiv og aktiv behandling, differensiell forsterkning av alternativ atferd (DRA) og differensiell forsterkning av annen atferd (DRO), i tillegg til vanskelige aspekter ved restriksjoner og straff. I den andre delen omtales temaer hvor man sikter på å utvide det atferdsanalytiske perspektivet for å sikre et mer optimalt resultat. Samtalebehandling, som kognitiv atferdsterapi og aksept- og forpliktelsesterapi (acceptance and commitment therapy - ACT), blir kortfattet beskrevet. Relasjonelle aspekter ved behandlingen har fått en heller stemoderlig behandling. Avslutningsvis er det et kapittel om «lovlig og etisk behandling». Det siste er vel ikke helt vanlig i bøker som omhandler psykososiale behandlingsmetoder, men synes viktig når det gjelder atferdsanalyse.

Boken er lettlest, og forfatteren beskriver informativt en del etiske og problematiske aspekter ved denne behandlingsmetoden. Imidlertid ble jeg langt fra overbevist om fortreffeligheten av å benytte seg av atferdsanalytiske prinsipper i miljøbehandlingen. Først og fremst savner jeg en mer forskningsmessig dokumentasjon når det gjelder metoden. Hva er gjort av forskning for personer med ulike psykiske lidelser? Hvordan skapes et miljø med hovedsøkelys på atferdsanalytiske prinsipper? Hvordan jobber de ulike yrkesgruppene med forskjellig teoretisk forankring sammen? Hvordan opplever brukerne en slik tilnærming?

Denne boken er nok best egnet for personer som utdanner seg innen helse- og sosialfagene, og for dem som skal jobbe med personer med utviklingshemning eller utviklingsforstyrrelser i barneog ungdomsårene. For psykiatere og leger som jobber med personer i disse gruppene, kan den gi en kort og grei innføring i noen av basisprinsippene for atferdsanalytisk tenkning og praksis.

Jan Ivar Røssberg

Institutt for klinisk medisin

Universitetet i Oslo 